\title{
MONITORING OF THE ANTIVIRAL POTENTIAL OF BEE VENOM AND WAX EXTRACTS AGAINST ADENO-7 (DNA) AND RIFT VALLEY FEVER VIRUS (RNA) VIRUSES MODELS By
}

MOSTAFA I. HASSAN ${ }^{1 *}$, ALY F. Mohamed, MONER A. AMER ${ }^{1}$, KOTB M. HAMMAD ${ }^{1}$ AND SABER A. RIAD ${ }^{1}$

Department of Zoology, Faculty of Science, Al-Azhar University ${ }^{1}$ and Virology Sector, VACSERA², Dokki, Egypt ( ${ }^{\star}$ Correspondence: mostafa012@gmail.com)

\section{Abstract}

This study monitored the antiviral potential of bee venom and four wax extracts, ethanol white and black beeswax (EWW/EBW) and acetone white and black beeswax (AWW/ABW) extracts. Two different virus models namely Adeno-7 as DNA model and RVFV as RNA virus models. End point calculation assay was used to calculate virus depletion titer. The depletion of viral infectivity titer of ABW to Adeno-7 virus showed strong antiviral activity recorded a depletion of viral infectivity titer (1.66 log $(10) / \mathrm{ml}$ ) that gave equal action with bee venom and more than interferon IFN (1 log (10)/ ml). On the other hand, antiviral activity of EBW showed a moderate potential, while AWW showed no antiviral activity. Finally EWW showed synergetic activity against Adeno-7 virus activity. Thus, activity of wax extracts to RVFV was arranged in order of IFN $>$ bee venom $>$ AWW \& EBW $>$ EWW and ABW recorded 3.34, 0.65, $0.5,0.34$ respectively. It is the first time to study the beeswax effect against DNA and RNA virus' models; acetone black beeswax recorded a depletion titer $1.66 \log (10) / \mathrm{ml}$. Keywords: Bee venom, Bee's wax, Antiviral, Cytopathology, DNA \& RNA virus models.

\section{Introduction}

Most people think in insects as enemies but some insects are friends not enemies. More than 900 therapeutics products were isolated from insects. Bee venom has antibacterial, antiparasitic, and antiviral properties (Guillaume et al, 2006). Many pharmacologically active components in honeybee, Apis mellifera venom, include peptides, enzymes, and biogenic amines that cause toxic reactions. The most important component is the peptide melittin, which comprises approximately $50 \%$ of bee venom (McKenna, 1993), the major components of honey bee venommelittin, phospholipase A2 and hyaluronidase (Schumacher, 1993). Melittin has been used for cancer gene therapy and human immunodeficiency virus (HIV-1) inhibition (Liu et al, 2001). Secreted phospholipaseA2 (sPLA2) from honey bee venom have potent anti-human immunodeficiency virus (HIV) activities. The secretary PLA2s block HIV-1 entry into host cells via a mechanism linked to
PLA2 binding to cells (Fenard et al, 2001). Bee-wax is produced by worker bees for building the honeycomb structure used for brood rearing and storing of honey, and pollen. The honeybee's wax has an extremely wide spectrum of useful applications including candles, cosmetics, and furniture polishes, anti-inflammatory, antibacterial (Krell, 1996). As the antimicrobial venom peptides of honey bee are present both on adult bees' cuticle and on nest wax, it was suggested that these substances act as a social antiseptic device, venom is spread over body cuticle and on comb wax of Apis species (Baracchi et al, 2011).

The aim of this study was to monitor the antiviral potential of bee venom and four beeswax extracts as antiviral activity against DNA and RNA virus models.

Materials and Methods

Colonization of honey bees: Six honey bee hives were conducted at experimental 
animal house, Al-Azhar Faculty of Science to produce wax and venom.

Bee venom collection (BV): Electric shock method was used to collect the bee venom from six bee hives during three weeks of 2014 (Bahreini et al, 2000). Two mg of dry bee venom were dissolved in $2 \mathrm{ml}$ media minimum essential medium Earl's Ramadan et al. (2009). Venom solution was filtrated by sterile $0.22 \mu 1$ syringe filter (Millipore, USA).

Collecting of bee's wax: Wax samples were collected from six bee reared in the animal house. White wax (WW) and black one (BW) were collected, then cut into small pieces, washed using tap water and left to dry at temperature $\left(27-31^{\circ} \mathrm{C}\right)$ for 2 to 10 days WW, BW (10g) were extracted (Miroslava et al, 2012) in $80 \mathrm{ml}$ solvents $70 \%$ ethanol, and aqueous acetone designated (EWW, EBW, AWW \& $A B W)$, respectively. Wax extracts were acidified with hydrochloric acid to $\mathrm{pH}$ 1.5. Samples were extracted at $40^{\circ} \mathrm{C}$ in incubator for seven days, shaken daily and filtrated through Whatman filter paper No. 5. Supernatants were dried in a rotary evaporator at $40^{\circ} \mathrm{C}$ for $2-3 \mathrm{hrs}$. for ethanol and 40-60 minutes for acetone. Two mgs of dry bee's wax extracts were dissolved in $2 \mathrm{ml}$ of $0.8 \%$ sodium chloride solution $0.004 \mathrm{ml}$ Tween- 80 . Extracts solutions were $0.2 \mu \mathrm{m}$ syringe filters filtrated.

Cell culture: Vero cells clone CCL-81, was grown in 199-Earls-medium supplemented with $10 \%$ fetal calf serum (FCS), $100 \mu \mathrm{g} / \mathrm{ml}$ Penicillin and $10 \mu \mathrm{g} / \mathrm{ml}$ Streptomycin. Fully grown monolayer was selected and the cells were trypsinized using trypsin solution $(0.25 \%)$. Cell suspension was dispensed as $100 \mu \mathrm{l} /$ well using automatic multichannel pipettes in 96 well flat bottom tissue culture plates.

Cytotoxicity: Cell viability of Vero cells under the effect of test wax \& venom samples was evaluated using MTT assay (Mosmann, 1983; Gerlier and Thomasset, 1986). Bee venom and wax extracts were added to cells at concentration of $1000 \mu \mathrm{g} / \mathrm{ml}$, control was included. Cell viability percentage was calculated as the following equation Viability $\%=$ Mean OD of sample/mean OD control cell x100.

Antiviral activity: Antiviral activity of bee venom and wax extracts against human adenovirus serotype 7 (Adeno-7) as DNA virus model and Rift Valley fever virus (RVFV) as RNA virus model were determined to evaluate the infectivity titer in Vero cells. According to Palamara et al. (1995) where confluent monolayer of Vero cells in 96-well tissue culture plates (TPP-Swiss), were divided into two sets, the first was treated with safe concentrations of bee venom and wax extracts $(100 \mu \mathrm{l} /$ well $)$ and incubated at $37^{\circ} \mathrm{C}$ as the following intervals; $3,6 \& 24 \mathrm{hrs}$; other was treated with venom and wax extracts free media and incubated for same intervals as a negative cell control. $\mathrm{CCID}_{50}$ was determined (Reed and Muench, 1938).

Comparison of antiviral activity of bee venom and wax with interferon: Vero cells at a concentration of $2 \times 105$ cells $/ \mathrm{ml}$ were maintained to confluence in 96 well cell culture plates. Four rows of cultured cells were treated with $100 \mathrm{IU} /$ well of interferon (Pegintron 80mg/0.5 (800. 000 IU/mg), Shering-Plough, USA) and the rest of the plate was supplemented with interferon (IFN) free media. Plates were incubated for $24 \mathrm{hrs}$. at $37^{\circ} \mathrm{C}$. Medium was discarded and wells were inoculated with 10 fold serially diluted virus models Adeno-7 \& RVFV and incubated at $37^{\circ} \mathrm{C}$ for 7 days. A 96 well cell culture plate for each virus was used. CCID50 was determined (Reed and Muench, 1938). Antiviral activity of bee wax and venom was compared (Denizot and Lang 1986) as the difference between mean virus infectivity titer inoculated on INF treated \& cells negative control was compared to difference between mean virus infectivity titer post-treatment.

\section{Results}

Bee venom and wax extracts cytotoxicity to Vero cells showed a relative relation 
between concentration and viability $\%$. IC50 was arranged in the order of EWW [1.6], AWW [1.6], EBW [12.5] ABW [0.5] and bee venom [0.4] $\mu \mathrm{g} / \mathrm{ml}$ (Fig.1). The data showed that bee venom and wax extracts showed variable antiviral potentials on Adeno-7 virus (DNA) and Rift Valley fever virus (RNA) virus models.

Antiviral activity (Tab. 2) of EWW, ABW, EBW, AWW \& BV against human adenovirus serotype 7 (Adeno-7) as DNA virus model showed an elevated virus infectivity titer post treatment recording $0.34 \log (10) \log (10) / \mathrm{ml}$, while rest of extracts showed a variable depletion rate of Adeno-7 virus infectivity titer in the order $1.66 \log (10) / 1 \mathrm{ml}, 0.66 \log$ (10)/1 ml, $0 \log (10) / 1 \mathrm{ml}$, and $1.66 \log$ (10)/1 $\mathrm{ml}$. The use of INF as $5 \mathrm{ngm} / \mathrm{ml}$ showed a depletion of virus infectivity titer in order of $1 \log (10) / 1 \mathrm{ml}$ post INF treatment compared with the virus control infectivity titer; $5.66 \log (10) / 1$.

The antiviral activity EWW, ABW, EBW, AWW \& BV against Rift Valley fever virus (RVFV) as RNA virus model (Tab. 3). A depletion of virus infectivity titer was $0.34 \log (10) / 1 \mathrm{ml}, 0.34 \log$ (10)/1 ml, $0.50 \log (10) / 1 \mathrm{ml}, 0.50 \log$ (10) $/ 1 \mathrm{ml}$, and $0.65 \log (10) / 1 \mathrm{ml}$. While, the INF showed a depletion of virus infectivity titer in order of $3.34 \log (10) / \mathrm{ml}$ post INF treatment compared with virus control infectivity titer, $8 \log (10) / 1 \mathrm{ml}$.

\section{Discussion}

Bee venom contains at least 18 active components, including enzymes, peptides, and biogenic amines, which have varieties of the pharmaceutical properties (Park et al, 2004). The normal eukaryotic cells with a low membrane potential, the cell membranes of prokaryotic cells showed a large membrane potential. So, many lytic peptides in honeybee products selectively disrupt the prokaryotic cell membrane rather than those of eukaryotic cell membrane (Moon et al, 2006).

In the present study, assessment of cell viability using methyl thiazolyltetrazolium assay (MTT) staining assay, as $100 \%$ of cell viability was induced when the Vero cells were treated with $1.6 \mu \mathrm{gm}$ of bee venom and bee's wax, this concentration proved safe and agreed with Yin et al. (2005) who reported the safe concentration of honeybee venom on Vero cells could be less than $1 \mu \mathrm{g} / \mathrm{ml}$. the cytoxic effect may be attributed to the ATP depletion (Eduard et al, 2002).

In the present study, the antiviral activity of bee venom against human adenovirus (Adeno-7) as DNA virus model revealed a moderate depletion of infectivity titer in order of $1.66 \log (10) / 1 \mathrm{ml}$, compared to rh-IFN $\alpha-2$ a that showed a little pit depletion rate in the order of $1 \log$ (10)/1 ml. ABW showed a better antiviral activity than AWW that might be due to the nature of each of them. On the contrary, antiviral activity of bee venom against RVFV as RNA virus model gave mild action compared to recombinant INF action that was superiorly affecting RVFV infectivity influence could be due to biological behavior of IFN, which enhances the induction of $\mathrm{Mx}$ protein and 2-5 Olygoadenylsynthetase 2,5- OAS (Guro, et al, 2006; Fahmy and Shoman, 2006) or interfering of IFN in viral replication cycle or inhibition of polymerase enzyme, (Mistchenko and Falcoff, 1987); Altinkilic and Brandner, 1988; Costa da Cunha et al, 1996; Samuel, 2001). The result also agreed with Ramadan et al. (2009) who recorded the virucidal activity of bee venom on Herpes simplex virus type-1(HSV-1) \& Adenovirus type-7 (adeno-7) as a DNA virus models studies revealed no significant decrease in HSV1 infectivity titer after 3, 6 \& 24 hrs. $(\mathrm{P}>0.05)$ while $48 \mathrm{hrs}$. later a significant viral depletion rate was recorded in the order of $1 \log (10) / 0.1 \mathrm{ml}$ was detected. The virucidal activity on Adeno-7 virus model showed no significance changes three hrs. post treatment. There was a significant depletion rate of virus infectivity titer 6 and $24 \mathrm{hrs}$. post treatment; $3.7 \log (10) / 0.1 \mathrm{ml}$ and $2.75 \log (10) / 0.1$ $\mathrm{ml}$ respectively. 
Also, the evaluation of virucidal activity of bee venom against RNA model virus of RVV revealed that there was a significant decreased in WNV infectivity titer post thermal treatment incubation at $37^{\circ} \mathrm{C}$ for 3, 6, $24 \& 48 \mathrm{hrs}$. post treatment gave $5.1 \log (10) / 0.1 \mathrm{ml}, 4.5 \log (10) / 0.1 \mathrm{ml}$, $2.1 \log (10) / 0.1 \mathrm{ml}$ and $0.55 \log (10) / 0.1$ $\mathrm{ml}$ respectively. The antiviral activity of bee venom of HSV-1 as a DNA model virus showed a non-significant decrease in the infectivity titer post thermal treatment. In the meantime, the antiviral activity of bee venom against Adeno virus sero-type-7 revealed that there was a nonsignificant decrease in Adeno-7 titer 3, 6 $\& 24 \mathrm{hrs}$ post incubation at $37^{\circ} \mathrm{C}$. Evaluation of the antiviral activity of bee venom against RNA model virus RVFV showed a non-significant decrease in Rift Valley virus titer after incubation period of 3,6 $\& 24 \mathrm{hrs}$ post treatment at $37^{\circ} \mathrm{C}$.

In the present study, antiviral activity of bee venom was also compared with that of the drug; interferon -2 a (IFN- $\alpha 2 a$ ). HSV-1 was insignificantly decreased recording $5.5 \log (10) / 0.1 \mathrm{ml}$ in the bee venom treated cells compared to significant decrease when treated with (IFN 2a) recording $3.2 \log (10) / 0.1 \mathrm{ml}$. In the meantime antiviral activity against adenovirus-7 recorded a significant decrease in virus infectivity titer recording $3.4 \mathrm{log}$ (10) $/ 0.1 \mathrm{ml}$ post bee venom compared with $3.25 \log (10) / 0.1 \mathrm{ml}$ post IFN treatment which mean that the in vitro studies of the effect of standard IFN used was the same as bee venom on the Adeno-7 virus. RNA model virus; RVFV was well influenced by bee venom than IFN where the virus infectivity titer recorded $1 \log (10)$ $/ 0.1 \mathrm{ml}$ post bee venom treatment compared with $2.5 \log (10) / 0.1 \mathrm{ml}$ virus infectivity titer post IFN treatment. The present results agreed with Mistchenko and Falcoff (1987) and Samuel (2001). But, the bee venom (BV) action against RVF virus (RVFV) as RNA virus model, recorded weak depletion of infectivity titer in order of $0.65 \log (10) / 1 \mathrm{ml}$. While the use of INF showed high depletion of infectivity titer in order of $3.34 \log (10) / 1$ $\mathrm{ml}$. This meant that in-vitro studies indicate weak action of honeybee venom (BV) on RVFV compared to the chemical drug INF action, which agreed with Altinkilic and Brandner (1988) and Costa da Cunha et al. (1996). In the same time, antiviral activity of ethanol white bee extract EWW against RVFV as RNA virus model, recorded mild depletion of infectivity titer in order of $0.34 \log (10) / 1 \mathrm{ml}$. While the use of INF showed high depletion of infectivity titer in order of 3.34 $\log (10) / 1 \mathrm{ml}$. On the other hand, antiviral activity of ethanol white honeybee extract EWW against human adenovirus (Adeno-7) as DNA virus model, recorded depletion infectivity titer in order of 0.34 $\log (10) / 1 \mathrm{ml}$. The use of INF showed high depletion of infectivity titer in order of $1 \log (10) / 1 \mathrm{ml}$. This indicated low action of ethanol white honeybee extract EWW on (RVFV), against human adenovirus (Adeno-7) compared to the chemical drug INF action. The recorded data revealed a resemblance to Mistchenko and Falcoff, (1987); Samuel (2001). Antiviral activity of acetone black honeybee wax extract ABW against Rift Valley fever virus as RNA virus model, recorded a depletion of infectivity titer in order of $0.34 \log (10) / 1 \mathrm{ml}$. While, the use of INF showed a depletion of infectivity titer in order of $3.34 \log (10) / 1 \mathrm{ml}$. But, the antiviral activity of acetone black honeybee extract $\mathrm{ABW}$ against human adenovirus (Adeno-7) as DNA virus model, recorded high depletion of infectivity titer in the order of $1.66 \log (10) / 1 \mathrm{ml}$. While the use of INF showed a depletion of infectivity titer in order of $1 \log (10) / 1 \mathrm{ml}$. So, invitro studies indicated low action of acetone black bee extract ABW on (RVFV), strong action against human adenovirus (Adeno-7) compared to INF action, data showed a resemblance to Mistchenko and Falcoff (1987); Samuel (2001); Moon et al. (2006) and Ghanem (2011).

Also, the results agreed with Filotti et 
al. (1967) despite they regarded the venom virucidal activity $24 \mathrm{hrs}$. post treatment. De-Clercq et al. (2000) proved that bee venom melittin inactivates HIV and aborts cell-to-cell fusion and HIV transmission due to high-affinity interaction with gp120, Mitsuishi et al. (2006) indicated that the direct addition of bee venom phospholipase A2 to 293A cells suppressed adenovirus plaque formation in number and size. De-Clercq et al. (2000) and Mitsuishi et al. (2006) proved that bee venom melittin inactivates HIV interaction with gp120

The Egyptian bees' wax have biological role as antibacterial, antiparasitic and antiviral properties not reported as a case of bee venom antimicrobial properties. Da Cunha et al. (2013) found that geopropolis is a type of propolis containing resin, wax and soil, collected by threatened stingless bee species showed antimicrobial and antiproliferative potential against cancer cell lines. Majiene et al. (2004) reported that propolis, a natural product produced by bees and contains plants' exudates mixed with bee wax, its ethanolic extracts were used for diseases' treatment and prevention, as having anti- bacterial, antiviral, antiinflammatory, antifungal, anesthetic and immunomodulating properties with structural compounds types of terpenoids, aromatic and aliphatic acid esters. Most of terpenoids are mono- and sesquiterpens: azulene, alphabisabolol, citral, valerenol, etc., which compositions depended on plants origin of propolis collected.

\section{References}

Altinkilic, BG, Brandner, S, 1988: Interferon inhibits Herps simplex virus-specific translation: a reinvestigation. J. Gen. Virol. 69, 2: 3107-12.

Bahreini, R, Fakhimzadenh, K, Nowzary, J, Nehzati, A, 2000: Design and construction of a venom collecting electric cage and its effects on honey production in honeybee colonies. Iran. J. Agri. Sci. 31, 2:333-9.

Baracchi, DA, Francese, SA, Turillazzi, SA, 2011: Beyond the antipredatory defense: honey bee venom function as a component of social immunity. Curr. Nutr. F. Sci. 58, 6/7:550-7. Costa da Cunha, CSC, Lebbe, M, Rybojad, F, Agbalika, F, Ferchal, C, et al, 1996: Longterm follow-up of non-HIV Kaposi's sarcoma treated with low-dose recombinant interferon alfa-2b. Arch. Dermatol. 132, 7:285-90.

da Cunha, MG, Franchin, M, de Carvalho Galvão, LC, de Ruiz, AL, et al, 2013: Antimicrobial and antiproliferative activities of stingless bee Melipona scutellaris geopropolis. BMC Compl. Altern. Med. Jan 28;13:23. doi: 10.1186/1472-6882-13-23

De-Clerq, E, 2000: Current lead natural products for the chemotherapy of human immunodeficiency virus (HIV) infection. Med. Res. Rev. 3, 1:365-9.

Denizot, F, Lang, R, 1986: Rapid colorimetric assay for cell growth and survival. J. Immun. Meth. 89, 5:271-7.

Eduard, H, Rosa, B, Carmen, D, 2002: Cytotoxicity mechanisms of sodium hypochlorite in cultured human dermal fibroblasts and its bactericidal effectiveness. Chemico-Biol. Interac. 139, 2:265-82.

Fahmy, AM, Shoman, SA, 2006: Antiviral activity of recombinant human interferon to Rift Valley fever virus and related mx-protein potential as a biomarker. J. Biomed. Sci. 21:34.

Fenard, D, Lambeau, G, Maurin, T, Lefebvre, J, Doglio, A, 2001: A peptide derived from bee venom-secreted phospholipase A2 inhibits replication of T-cell tropic HIV-1 strains via interaction with CXCR4 chemo-kine receptor. Mol. Pharmacol. 60:341-7.

Filotti, A, Derevici, Toacsen, E, 1967: Action of bee venom on fixed rabies virus. Arch. Roum. Pathol. Exp. Microbiol. 26, 4:741-6.

Gerlier, D, Thomasset, N, 1989: Use of MTT colorimetric assay to measure cell activation. J. Immun. Meth. 94:57-63.

Ghanem, NB, 2011: The antimicrobial activity of some honey bee products and some Saudi folkloric plant extracts. J. K. Uni. Sci. 23, 2: 57-62.

Guillaume, C, Calzada, C, Lagarde, M, Schrevel, J, Deregnaucourt, C, 2006: Interplay between lipoproteins and bee venom phospholipaseA2 in relation to anti-Plasmodium toxicity. J. Lipid Res. 47:1493-506.

Guro, M, Pedersen, A, Johansen, A, Ragnar, L, Olsen, B, et al, 2006: Stimulation of type I IFN activity in Atlantic salmon (Salmosalar L.) leukocytes: Synergistic effects of cationic proteins and $\mathrm{CpG}$ ODN. Fish Shellfish Immun. 20, 6:503-18

Krell, R, 1996: Value-added products from beekeeping. Rome: FAO, 409. 
Liu, YH, Chen, S, Zhang CX, 2001: Advance in melittin research. Entomol. Knowl. 38, 6: 410-3.

Majiene, D, Trumbeckaite, S, Grūnoviene, D, Ivanauskas, L, Gendrolis, A, 2004: Investigation of chemical composition of propolis extract. Medicina (Kaunas). 40, 8:771-4.

McKenna, W, 1993: Killer bees: what the allergist should know. Pediatr. Asthma aller. immunol. 6:275-85.

Miroslava, K, Vukovic, N, Chilebo, R, Hascik, P, Katarina, RJC, et al, 2012: The antimicrobial activity of honey, bee pollen loads and beeswax from Slovakia. Arch. Boil. Sci. Belgrade. 64, 3:927-43.

Mistchenko, AS, Falcoff, R, 1987: Recombinant human interferon-inhibits adenovirus multiplication in vitro. J. G. Virol. 68:941-4.

Moon, DO, Park, SY, Heo, MS, Kim, KC, Park, CK, et al, 2006: Key regulators in bee venom-induced apoptosis are Bcl-2 and caspase-3 in human leukeic U937 cells through down regulation of ERK and AKT. Int. Immunopharm. 6:1796-807.

Mosmann, T, 1993: Rapid colorimetric assay for cellular growth and survival: application to proliferation and cytotoxicity assay. J. Immun. Meth. 65:55-63.

Table 1: Viability \% of Vero cell lines post treatment with serially diluted wax extracts \& venom diluted using (MTT).

\begin{tabular}{|c|c|c|c|c|}
\hline \multirow{2}{*}{$\begin{array}{c}\text { concentration } \\
\mu \mathrm{g} / \mathrm{ml}\end{array}$} & \multicolumn{4}{|c|}{ Cell viability (\%) } \\
\cline { 2 - 5 } & EWW & ABW & EBW & AWW \\
\hline 100 & 9.60 & 17.42 & 32.54 & 8.10 \\
\hline 50 & 34.69 & 24.51 & 50.17 & 16.63 \\
\hline 25 & 48.60 & 43.72 & 66.01 & 25.16 \\
\hline 12.5 & 64.44 & 67.37 & $98.62 *$ & 30.60 \\
\hline 6.3 & 70.60 & 91.17 & 98.70 & 33.19 \\
\hline 1.6 & $100.42 *$ & $105.65 *$ & 97.12 & 47.66 \\
\hline 0.8 & 101.71 & 97.33 & 97.62 & 54.19 \\
\hline 0.4 & 98.70 & 97.69 & 97.26 & 66.59 \\
\hline 0.2 & 102.57 & 97.55 & 96.27 & 79.77 \\
\hline 0.1 & 99.27 & 101.20 & 98.55 & 88.30 \\
\hline 0.05 & 98.62 & 99.13 & 100.56 & $91.67 *$ \\
\hline 0.03 & 98.19 & 100.63 & 97.86 & 91.31 \\
\hline \multicolumn{4}{|c|}{$*$ bee's wax safe concentrations. } \\
\hline
\end{tabular}

Table 2: Antiviral activity of bee wax extracts venom on human adenovirus serotype 7 (Adeno-7) compared to INF.

\begin{tabular}{|c|c|c|c|c|}
\hline Sample & V.T.Pre-TTT & V.T.Post-TTT & Log difference & $(\%)$ \\
\hline EWW & \multirow{6}{*}{5.66} & 6.00 & - +0.34 & 0.00 \\
\hline ABW & & 4.00 & 1.66 & 55.33 \\
\hline EBW & & 5.00 & 0.66 & 16.50 \\
\hline AWW & & 5.66 & 0.00 & 0.00 \\
\hline $\mathrm{BV}$ & & 4.00 & 1.66 & 55.33 \\
\hline INF & & 4.66 & 1.00 & 27.32 \\
\hline
\end{tabular}

V.T.Pre-TTT = virus titer pre-treatment, V.T.Post-TTT $=$ virus titer post treatment.

Table 3: Antiviral activity of bee wax extracts, bee venom against Rift Valley fever virus as compared to INF.

\begin{tabular}{|c|c|c|c|c|}
\hline Sample & V.T.Pre-TTT & V.T.Post-TTT & Log difference & $\%$ \\
\hline EWW & \multirow{6}{*}{8} & 7.66 & 0.34 & 5.16 \\
\hline ABW & & 7.66 & 0.34 & 5.16 \\
\hline EBW & & 7.50 & 0.50 & 7.69 \\
\hline AWW & & 7.50 & 0.50 & 7.69 \\
\hline BV & & 7.25 & 0.65 & 10.40 \\
\hline INF & & 4.66 & 3.34 & 91.25 \\
\hline
\end{tabular}

